UDC 631.147(091)

COBISS.SR-ID 250171916

Professional paper

Acta Agriculturae Serbica, Vol. XXII, 43 (2017); 67-88

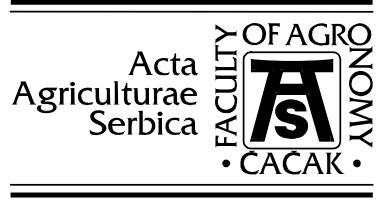

\title{
Plant production by the concept of organic agriculture in the world and Serbia - history and current status
}

\author{
Jelena Golijan ${ }^{1}$, Milovan Veličković ${ }^{1}$, Bojan Dimitrijević ${ }^{1}$, Dimitrije \\ Marković $^{2}$ \\ ${ }^{1}$ Faculty of Agriculture, University of Belgrade, Belgrade-Zemun, Serbia \\ ${ }^{2}$ Faculty of Agriculture, University of Banja Luka, Banja Luka, Bosnia and \\ Hercegovina \\ *Corresponding author: helena.ilios@gmail.com
}

\begin{abstract}
Unlike conventional agriculture, organic farming, as a form of sustainable agriculture, and its production methods preserve and upgrade biodiversity of the soil and biodiversity of the entire ecosystem by protecting the environment, plants, and human health. It appeared at the beginning of XX century in Poland and has been spreading in many countries worldwide ever since. In 2015, this type of agricultural production was implemented at a global level on an area of 50.9 million ha. The largest areas are located in Oceania (22.8 mil. ha) and Europe (12.7 mil. ha), whereas grass areas make up the most, and arable land makes up only 15\% there of. In the period 2014-2015, the area increased by $6.5 \mathrm{mil}$. ha at the global level. In 2015, the largest increase was recorded in Oceania (23.2\%) and in 98 countries around the world, while a decrease was recorded in 32 countries. Europe performs $1 / 4$ of the world's organic production. In Serbia, organic production makes up 15298 ha (13398 ha belongs to arable land, 1899 ha to meadows and pastures). The largest number of producers is located in Vojvodina, and in Western and Southern Serbia. Cereals have a leading role with a production area of 2182.89 ha. Having in mind the great potentials for organic production in Serbia, experts' plan for the next decade is to increase the area for this type of agricultural production by $20 \%$.
\end{abstract}


Key words: organic agriculture, historical development, legislation, production areas.

\section{Introduction}

Organic agriculture appeared as a response to the environmental pollution, urbanization and preservation of plants and animals (Milenković and Tasić, 2013; Kolašinac et al., 2017). Agriculture is usually developed just as much as the society it self. Wholesome and good quality land is a key component of sustainable agriculture. Excessive use of agrochemicals can cause various disorders in biological balance of agro ecosystems and beyond (Veličković and Golijan, 2015). Conventional (industrial) agriculture is to ensure maximum production in terms of quantity and quality. The need for a healthier environment, as well as a number of negativities caused by the conventional agriculture have led to the development of alternative directions in agriculture including ecological systems such as organic production (Kovačević et al., 2011). One of the fundamental rules of the eco-agriculture is the rule of nature simulation. Organic production seeks to apply the concept of multifunctionality in practice in the specific working and living space, including biodiversity (Knickle, 2000), autochthonous species and breeds, care for animals, but also repopulation of rural areas, as well as increase of social and economic standards of living (Šiljković, 2002). It has been proved that organic farming is a way to increase the number of species and promote greater abundance of groups of organisms in relation to the conventional production, especially respecting the differences and the presence of species of insects, plants, soil micro and macro fauna (Veličković et al., 2016). Organic farming preserves and improves the biodiversity of land, controls and increases the fertility of soil with its methods, protects environment and applies the highest standards of protection of the health of animals and plants (Ugrenović and Filipović, 2012; Popović et al., 2016).

In addition to the term organic farming, Vehapi states that the following terms are often met:

1) Biological agriculture - tends to point out the importance of protection of living organisms in nature, and the activation of the biological processes, which is the basic similarity with organic farming (both types of agricultural production prefer to use organic materials to the inorganic non-living things);

2) Natural agriculture - a term that comes from Japan, which is disputed a lot, because there is no clear criteria regarding the differences between natural agriculture and the one that is not (though, in its original meaning, this form of agriculture emphasizes the importance of using natural substances, but also includes the avoidance of many human activities in agriculture, which is different from the organic farming);

3) Alternative agriculture - the term that appears with the aim to replace all previously used terms for those practices and entrepreneurships which differ from the conventional agricultural activities; 
4) Sustainable Agriculture - formed as part of a broader concept of sustainable development - a term referring to the agricultural production at which the benefits that it produces at present do not harm the future generations (each organic agriculture is sustainable agriculture, but any sustainable agriculture is not an organic agriculture, there may be a compromise);

5) The Agriculture with minimum investment (for low input agriculture) - a term which refers to agricultural production in which the external input (e.g., agrochemicals and energy) are reduced, but not excluded, so that a more precise term would be agriculture with low external investments;

6) Integrated agriculture - denotes the type of agricultural production with the more rational and more skilled use of agrochemicals, but it certainly does not tend to completely prevent their use;

7) Ecological Agriculture - in contrast to the integrated management, it aims to completely prevent the entry of agrochemicals under the environmental system and thereby prevent any harmful effects for the environment;

8) Agro-ecology - as a scientific discipline concerned with the "application of ecological principles and concepts in education and management of sustainable food systems" (since in the first place it studies the ecological conditions of agricultural production (soil, air, water ...) and it may have nothing to do with organic farming;

9) The traditional agriculture - is based on the old methods of domestic production systems that include plant and animal production. Although due to its ecological character it can quickly turn into organic production, but it cannot be identified with it (organic farming is a broader concept which is based on the latest developments and findings and does not aspire to return to the past;

10) Radical agriculture - means "restore agriculture to its nature, but this time enhanced with the aim to serve not only for human existence, but to create an environment of safe and dignified life." Such an environment can be provided only by organic farming, which by its character is the radical turn in comparison to conventional agriculture. The use of those terms depends on speaking areas. Thus, the Latin and the German-speaking areas use the term 'biological agriculture', the Anglo-Saxon speaking areas use the term 'organic', while the Scandinavian countries use the term 'organic farming'. Therefore, in addition to the term 'organic farming' that has been adopted in Serbian language, the terms 'organic" or 'biological' and even 'radical agriculture' may be used as acceptable (Vehapi,2014).

At the UN conference "On the Environment and Sustainable Development" held in Brazil in 1992, the strategy of sustainable agriculture and rural development was adopted, with the set of four principles for the recognition of organic farming (Vrdoljak i sar, 2010):

1) the principle of health,

2) the ecological principle,

3) the principle of fairness and 
4) the principle of nurturing and care.

The ecological production also deals with the natural resistance of plants such prevention against diseases and pests. These characteristics can lead to the conclusion that the production is aimed to be made more convenient and less stressful for the production animals. It also means pollution prevention and environment preservation, since this kind of production does not pollute the soil and protects from disrupting the natural system. The most important advantage of organic production is the preservation of human health.

Organic food market in the world records a rapid growth, while Serbia is still underdeveloped. The total area under organic production in Serbia covers an area of 15298.02 ha (The Ministry of Agriculture and Environmental Protection, 2016). Consumers in most countries around the world have a positive attitude to the organic produced food (Conner, 2004; Bähr et al., 2004; Zander et al., 2011). The most common reason that impels the consumers to consume this type of products, and propels manufacturers to deal with the production of the same, is the care of their own health, because consumers believe that organic products are healthier and that they have a higher content of various nutrients compared to conventionally produced food, and thus that they are safer for consumption (Golijan and Veličković, 2015; Marques Vieira et al., 2013).

\section{Historical development of organic production and legal regulations}

Organic farming appears at the beginning of the twentieth century in Poland, when Dr. Rudolf Steiner gave a series of lectures on the theme of "Spiritual foundations for the reconstruction of agriculture" in Koberwitz, in 1924, followed the next year his ideas implemented in Switzerland Hans Mueller. Then in the German-speaking countries followed its development, which was preceded by the establishment of the theoretical foundations of organic-biological agriculture by Hans Peter Rush and Hans Mueller. Sir Albert Howard in 1940, after years of studying organic agriculture, published the book "Agricultural testament", pointing out that nature conservation organic production system is also a key factor not only the preservation of the land, but also to increase its long-term fertility.

In the UK, in 1946 appeared the movement of organic producers and the "Association for the land" under the direction of Lady Eve Balfour, who carried out the first comparative examination of organic and conventional production (known as "The Haughley Experiment"). Jerome Rodale cited as the originator of organic agriculture in the United States, and under his leadership in 1942 the first issue of the magazine on organic agriculture. Japan is referred to as a country in which they are established the first school of "natural of agriculture" in 1935, where Mokichi Okada stands out as the main founder. Even in the early 1960s produced food with less use of pesticides and fertilizers by a group of Lemaire 
Boucher in France, New Alchemy Institute and Ecology Action in the United States (Vehapi, 2014).

With the advent of the book "Silent Spring" in 1962, which states drastically harmful effects of DDT and pesticides on the environment, after ten years following the ban of the use of DDT in the United States (Oljača, 2012). After all the seof previous developments in the field of organic agriculture, generated numerous scientific institutions seventies and eighties. Thus, in 1972 gets up the International Federation of Organic Agriculture Movements IFOAM (International Federation of Organic Agriculture Movements), which brings together 104 countries with over 750 organizations (Beleski et al, 2012), and the first issue of the international standards already in 1980.

Then in 1973 in Switzerland founded the Research Institute of Organic Agriculture - FiBL (Forschungsinstitut fuer Biologischen Landbau), followed by the expansion of organic agriculture in many countries around the world to this day. The first fair BioFach organic products was established in the Nürburgring in 1990. The first legislation on organic production in the countries of Europe adopted in 1991 (ECC No. 2092/91). This legislation is the first legislation regulating the legal provisions related to organic seeds and planting material, and from January 1, 2000 introduced their use (Berenji, 2009). 1999 was a significant year as the adoption of guidelines by FAO and IFOAM to the production, processing, labeling and marketing of organic products. Based on these guidelines in 2000 but are grounded Japanese standards (JUS) for organic products (Shi-mingle and Sauerborn, 2006). Current data indicate that in all countries of the world organic land is constantly expanding, and the market reflects the high growth rate (www.fibl.org).

Organic production is such a system of agricultural production that is completely governed by law. This system of production results from the standards established by the IFOAM. In all countries, the legal regulations related to organic agriculture are based on the IFOAM principles. The development of non-government sector of organic agriculture started in Serbia in 1990 when the Association Terra's was founded in Subotica. This Association has been a driving force of the development of the organic production sector in Serbia since its foundation. SIDA (Sweeden), Avalon (the Netherlands) and Diaconia (Germany) were the first international organisations that promoted and facilitated the development of organic agriculture in our country through their projects. The German Society for International Cooperation - GIZ (DeutscheGesellschaftfür Internationale Zusammenarbeit) supported the Association Terra's in 2003, hence the cooperation with the German control organisation BSC was established. This was the beginning of the control organisation in Serbia (Kalentić et al., 2014). The Law on Organic Production and Organic Products was adopted in Serbia in 2006 (RS Official Gazette, issue 62/2006). This Law regulates production and processing of agricultural and other products within the organic production system, processing, storing, transport, 
labelling, declaring, marketing, certification and re-certification of these products (Roljević et al., 2009). The Rulebook on Control and Certification in Organic Production and on Organic Production Methods was adopted in July, 2011 (RS Official Gazette, issue 48/2011). The organic products control system in our country was established in accordance with the control system prescribed by the EU Regulations (Article 33 of the Commission Regulations (EC) No. 834/2007 and 889/2008). Moreover, the National Action Plan for Organic Agriculture Development in Serbia for the period 2013-2017 was defined. Organic agriculture in Serbia is governed by the laws, decrees and regulations, the most important being: the Law on Organic Production (RS Official Gazette, issue. 30/2010); Control Regulation and certification in organic production and methods of organic products RS Official Gazette, issue 48/2011); Rules on the modifications to the Ordinance on control and certification in organic production and methods of manufacture of organic (RS Official Gazette, issue 40/12). In accordance with the law, at the end of 2010 was established by the competent authority for organic production in the Directorate for national reference laboratories of the Ministry of Agriculture, Forestry and Water Management. Activities within its jurisdiction began to perform in January 2011. The process of full harmonization of Serbian legislation and the EU in the field of organic production has not yet been completed (Kalentić et al., 2014).

In order to designate a product as the "product of organic agriculture" and to apply the logo "organic agriculture", it is necessary to certify the product through the process of certification. Certification itself is a process by which a certification body issues an approprite certificate after performed control. This certificate confirms that the controlled product complies with the law and rulebooks on organic production, while control is a process of determination of complience of the registered production with organic production stnadards. A transition period, i.e. conversion period is a period of time necessary to establish a farm management system, improve soil fertility, as well as its biological activity, and in such a way to develop sustainable agroecosystem; this is the period when a grower gains experience in the application of organic production methods (Mićić et al., 1996). The duration of the transition period is three years but it may be extended or shortened depending on specific condtions - obeying preseribed rules or specific environmental factors (Mirecki et al., 2011, Veličković and Golijan, 2015).

\section{Oragnic agricultural land}

In 2015, at the global level, organic farming was carried out on a total area of 50.9 million ha. Continent in which this aspect of production is carried out on the largest numbers is Oceania with 22.8 million hectares (taking a share of $45 \%$ of the global total organic farmland), followed by the equipment (12.7 million ha), South America (6.7 million ha), Asia (about 4 million ha), North America (about 
3 million hectares) and Africa (1.7 million ha) (Table 1). The country in which saw the biggest increase in the area under organic production in 2015 is Australia (4.4 million ha), in which the largest share - 97\%, occupy pastures (grazing areas), followed by Argentina and the United States (www.fibl.org). The total area under organic production is increasing at an average annual rate of change of $6.7 \%$ (Golijan and Popović, 2016). On a global level, in the structure of the area under the organic farming dominant grass surface $(60 \%)$, and cultivated area represents about $15 \%$ of the total area for organic agriculture (Bulatović, 2011).

Table 1. World: Organic agricultural land (including in-conversion areas) and regions' ahares of the global organic agricultural land 2015

\begin{tabular}{|c|c|c|}
\hline Region & $\begin{array}{c}\text { Oragnic agricultural } \\
\text { land (ha) }\end{array}$ & $\begin{array}{c}\text { Regions' shares of } \\
\text { the global organic } \\
\text { agricultural land }\end{array}$ \\
\hline Africa & 1.683 .482 & $3 \%$ \\
\hline Asia & 3.965 .289 & $8 \%$ \\
\hline Europe & 12.716 .969 & $25 \%$ \\
\hline $\begin{array}{c}\text { Latin } \\
\text { America }\end{array}$ & 6.744 .722 & $13 \%$ \\
\hline $\begin{array}{c}\text { North } \\
\text { America }\end{array}$ & 2.973 .886 & $6 \%$ \\
\hline Oceania & 22.838 .513 & $45 \%$ \\
\hline Total & $\mathbf{5 0 . 9 1 9 . 0 0 6}$ & $\mathbf{1 0 0 \%}$ \\
\hline
\end{tabular}

Source: Willer and Lernoud, 2017

Looking at the global level, in ten countries are the largest area under organic production, of which Australia with 22.69 million ha occupies a leading position, and is followed by Argentina (3.07 million ha), the USA (2.03 million ha), Spain (1.97 million ha), China (1.61 million ha), Italy (1.49 million ha) (Fig.1), France (1.38 million ha), Uruguay (1.31 million ha), India (1.18 million ha) and Germany (1.09 million ha) (www.fibl.org).

The share of world's agricultural land occupied by organic production is only $1.1 \%$. In this regard, at the global level, has the highest share of Oceania with $5.4 \%$, followed by Europe with $2.5 \%$ (Table 2), in which, the share of EU countries is $6.2 \%$. In Europe, the primary site with the highest proportion of an organic agricultural land has Lichtenstein, in which the organic production is carried out on more than $30 \%$ of agricultural land, followed by Austria from $21.3 \%$ (with the highest proportion in the EU), Sweden with 16.9\%, Estonia with 16.5\%, Sao Tome and Principe (13.8\%), Switzerland (13.1\%), Latvia (12.8\%), Falkland Islands (12.5\%), Italy (11.7\%), Czech Republic (11.3\%), Finland (10\%) (FAOSTAT, 2017; Eurostat, 2017). 


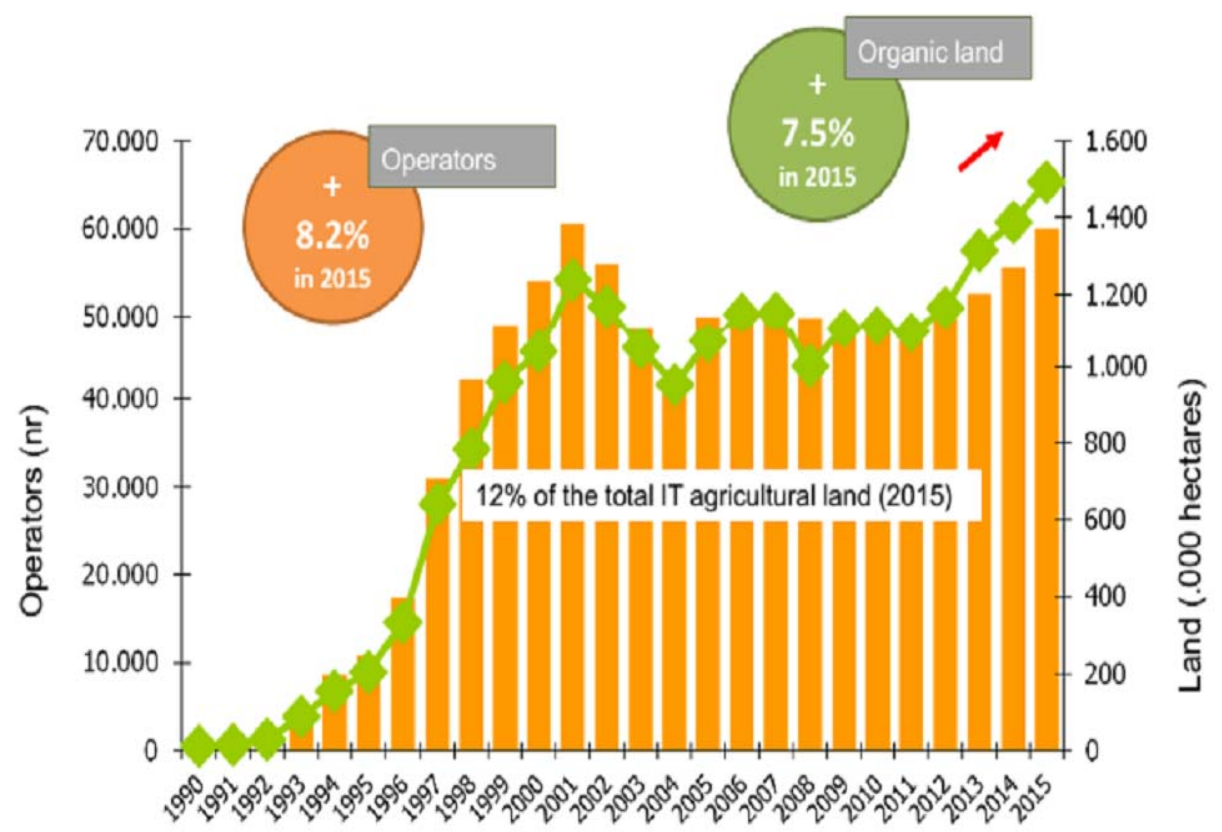

Figure 1. Italy: Development of organic agricultural land and operators 19902015 (Source: Solfanelly, 2017)

Table 2. World: Organic agricultural land (including in-conversion areas) and shares of total agricultural land by region 2015

\begin{tabular}{|c|c|c|}
\hline Region & $\begin{array}{c}\text { Oragnic agricultural } \\
\text { land (ha) }\end{array}$ & $\begin{array}{c}\text { Shares of total } \\
\text { agricultural land }\end{array}$ \\
\hline Africa & 1.683 .482 & $0.1 \%$ \\
\hline Asia & 3.965 .289 & $0.2 \%$ \\
\hline Europe & 12.716 .969 & $2.5 \%$ \\
\hline $\begin{array}{c}\text { Latin } \\
\text { America }\end{array}$ & 6.744 .722 & $0.9 \%$ \\
\hline $\begin{array}{c}\text { North } \\
\text { America }\end{array}$ & 2.973 .886 & $0.7 \%$ \\
\hline Oceania & 22.838 .513 & $5.4 \%$ \\
\hline Total & $\mathbf{5 0 . 9 1 9 . 0 0 6}$ & $\mathbf{1 . 1 \%}$ \\
\hline Source: & & \\
\hline
\end{tabular}

(Source: Willer and Lernoud, 2017)

Willer and Lernoud (2017) reported that they are in comparison with 1999, when 11 million ha was under organic production, the area up to 2015 increased 
of almost five-fold, and in a period of one year-from 2014 to 2015 were $15 \%$ and 6.5 million hectares (mainly due to the flat area in Australia for 4.4 million ha). During 2015, organic farmland has increased on all continents of the world except Latin America, where the area decreased by 85.855 ha (Table 3). The highest growth of $23.2 \%$ was recorded in Oceania, while the total increase in the area under organic production was recorded and in 98 countries worldwide, a decline in 32 countries.

Table 3. World: Organic agricultural land (including in-conversion areas) by region: growth 2014-2015

\begin{tabular}{|c|c|c|c|c|}
\hline Region & $\begin{array}{l}\text { Oragnic } \\
\text { agricultural } \\
\text { land (ha) } \\
2014\end{array}$ & $\begin{array}{c}\text { Oragnic } \\
\text { agricultural } \\
\text { land (ha) } \\
2015\end{array}$ & $\begin{array}{l}1 \text { year } \\
\text { growth } \\
\text { (ha) }\end{array}$ & $\begin{array}{l}10 \text { years } \\
\text { growth (ha) }\end{array}$ \\
\hline Africa & 1.260 .619 & 1.683 .482 & $\begin{array}{c}+ \\
422.863\end{array}$ & $\begin{array}{c}+ \\
1.012 .844\end{array}$ \\
\hline Asia & 3.567 .578 & 3.965 .289 & $\begin{array}{c}+ \\
397.711 \\
\end{array}$ & $\begin{array}{r}+ \\
965.736 \\
\end{array}$ \\
\hline Europe & 11.757 .176 & 12.716 .969 & $\begin{array}{c}+959.79 \\
3 \\
\end{array}$ & $\begin{array}{c}+ \\
5.403 .552 \\
\end{array}$ \\
\hline $\begin{array}{c}\text { Latin } \\
\text { America }\end{array}$ & 6.830 .577 & 6.744 .722 & -85.855 & $\begin{array}{c}+ \\
1.795 .194\end{array}$ \\
\hline $\begin{array}{l}\text { North } \\
\text { America }\end{array}$ & 2.458 .466 & 2.973 .886 & $\begin{array}{r}+ \\
515.420 \\
\end{array}$ & $\begin{array}{c}+ \\
1.181 .314\end{array}$ \\
\hline Oceania & 18.532 .416 & 22.838 .513 & $\begin{array}{c}+ \\
4.306 .098\end{array}$ & $\begin{array}{c}+ \\
10.406 .693\end{array}$ \\
\hline Total & 44.403.835 & 50.919 .006 & $\begin{array}{c}+ \\
6.515 .171\end{array}$ & $\begin{array}{c}+ \\
20.761 .478\end{array}$ \\
\hline
\end{tabular}

(Source: Willer and Lernoud, 2017)

In Europe, where the area covered by organic products spread over 12.7 million ha, one-half of the area is located in only four of the earth-Spain, Italy, France and Germany (Schaack, 2017; Willer, 2017; Solfanelli, 2017; Lacarce, 2017; Padel, 2017) (Fig. 2), of which Spain has a leading role to 1.97 million ha, followed by Italy and France. In comparison to 2014, in 2015 in Europe there is a growth of organic farmland for more than a million ha, and at the last decade, this growth increased by 74\% (Fig. 3) (Willer, 2017; Popović et al., 2017). 


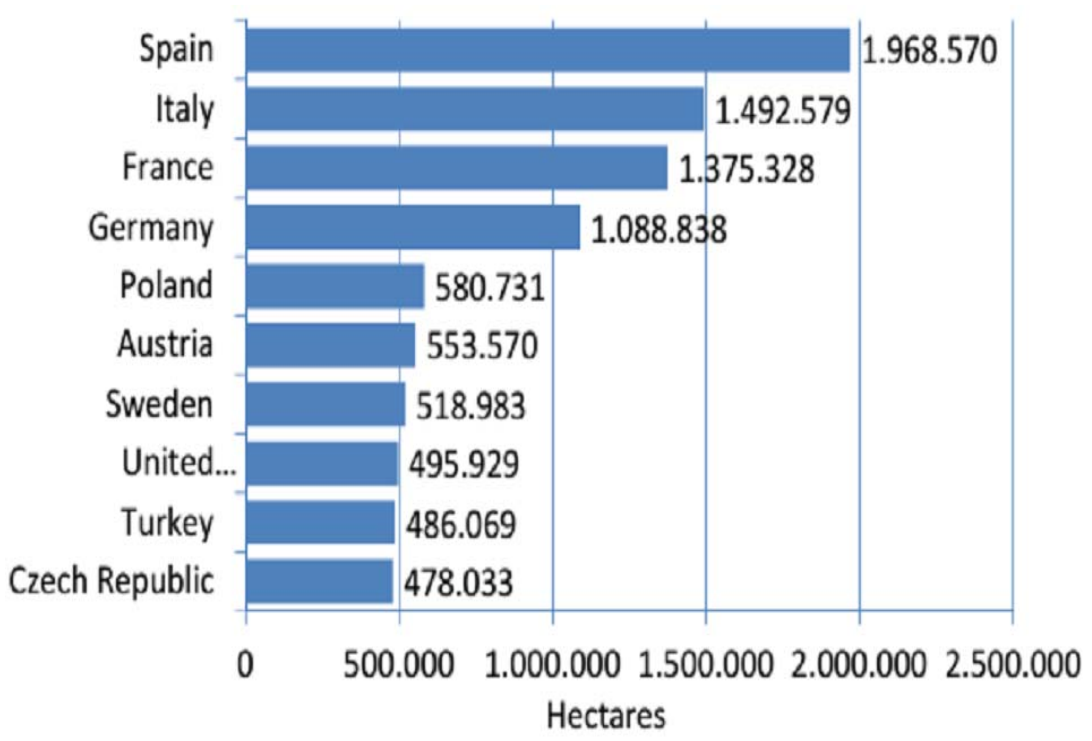

Figure 2. Europe: The ten countries with the largest organic area 2015. (Source: FiBL-AMI survey 2017, based on national data sources and Eurostat; Willer 2017)

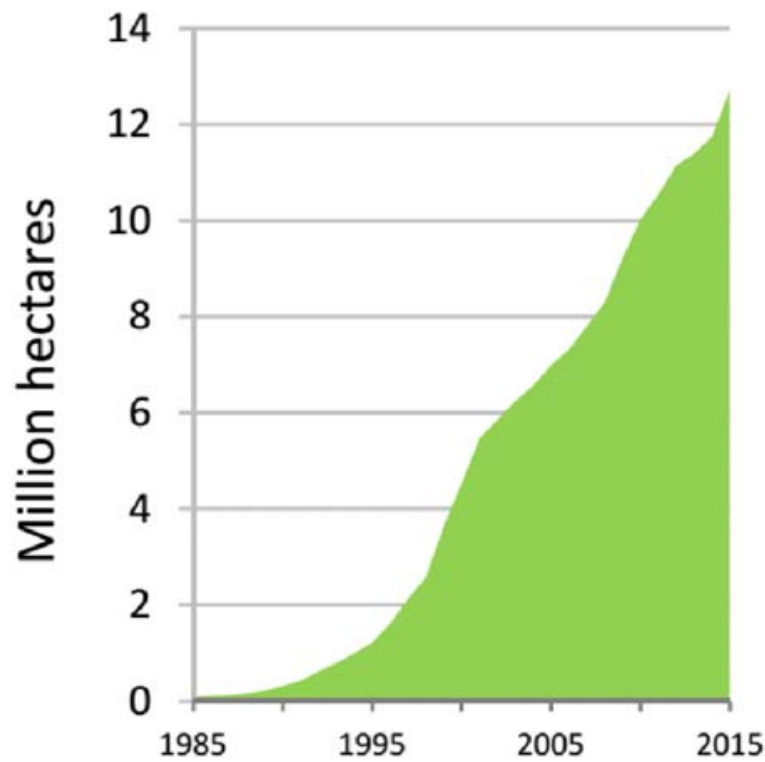

Figure 3. Europe: Growth of the organic agricultural land 1985-2015 (Source: FiBL survey 2017 www.organic world.net, Willer 2017) 
Looking at the country, according to recent data Willer (2017), in 2015 in ten countries (Fig. 4) recorded very strong growth of organic agricultural land-largest in Spain (to 258095 ha) and France (to 256483 ha ) (Fig.5 and 6).

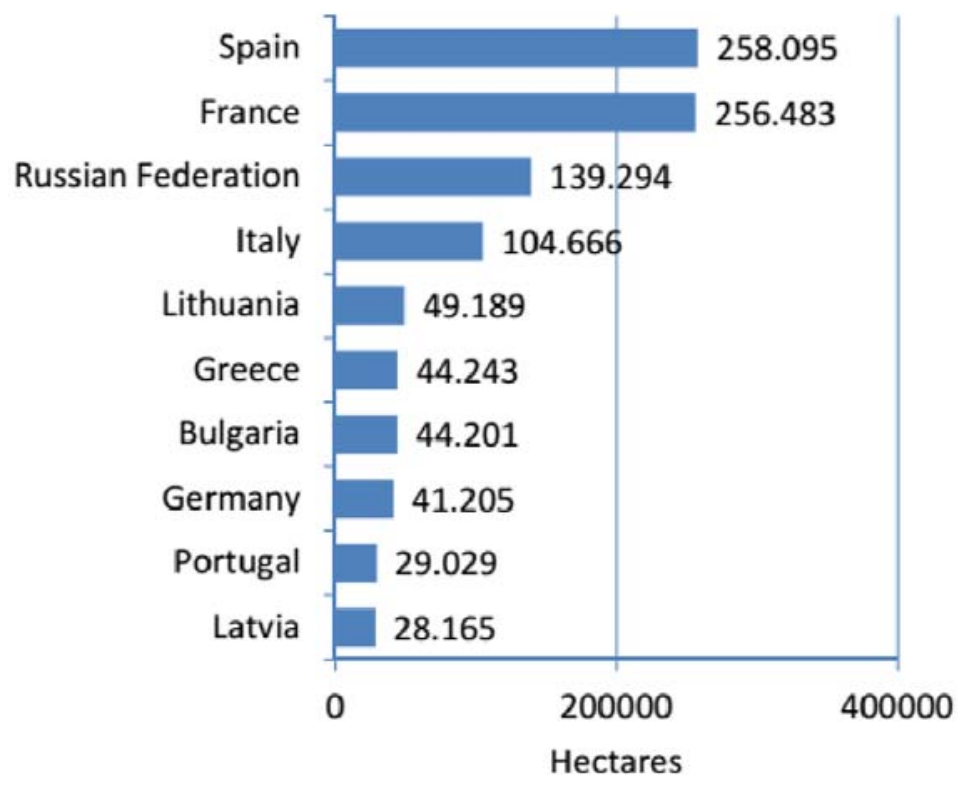

Figure 4. Europe: The 10 countries with the highest growth of organic agricultural land in 2015 (hectares).

(Source: FiBL AMI survey 2017 based on Eurostat and national data sources, Willer 2017) 
Certified areas (ha)

Number of operators

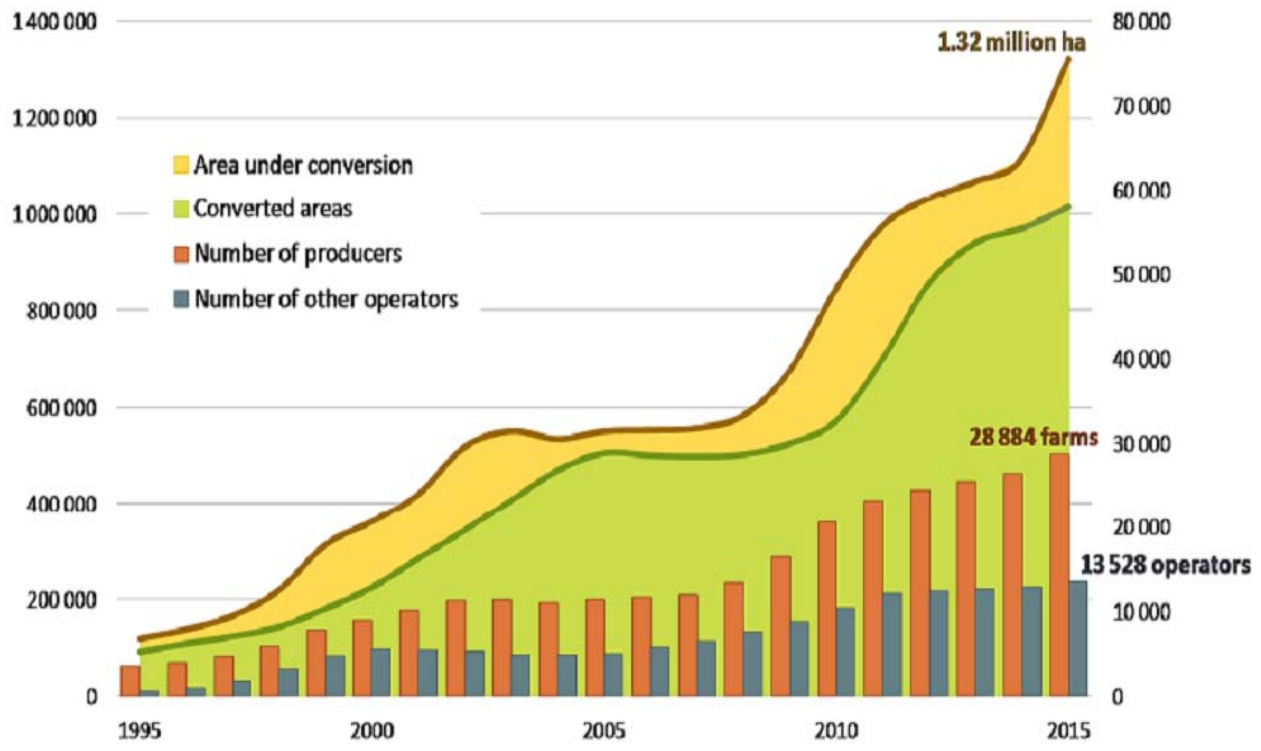

Figure 5. Evolution of organic production in France

(Source: Agence Bio, Certification 2015 - Lacarce 2017) 


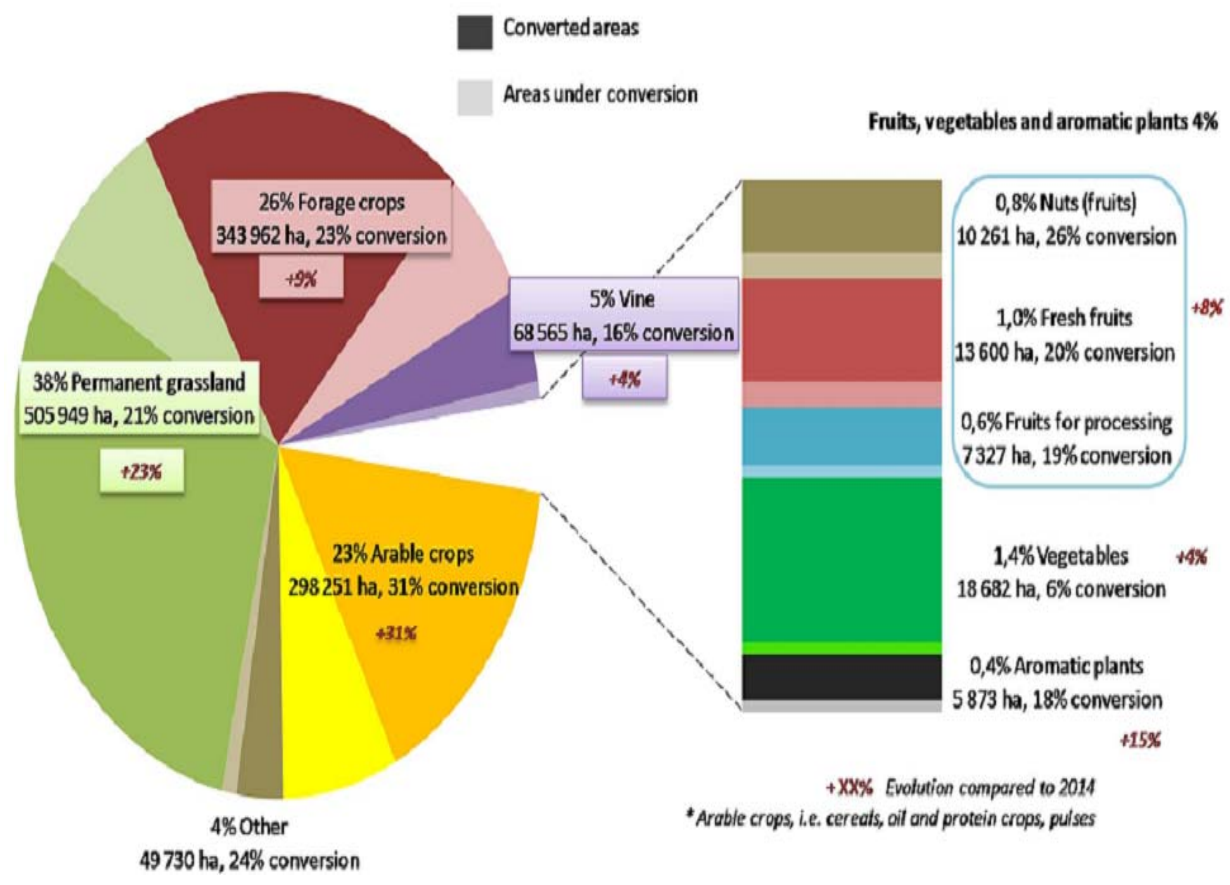

Figure 6. French organic land use

(Source: Agence Bio, Certification 2 - Lacarce 2017)

According to the same source, among the 10 countries in Europe with the highest growth of organic agricultural land in 2015, the highest growth was recorded in Bosnia and Herzegovina (63\%), followed by Serbia $(60 \%)$ and Bulgaria (59\%).

One quarter of the world's organic production is concentrated on the European continent, where a total of 12.7 million ha, even 11.2 million halocated in EU. In countries CPC (EU Candidate and Potential Candidate countries: Albania, Bosnia and Herzegovina, Macedonia, Montenegro, Serbia, Turkey), the share of area under organic production is still low-only $1.1 \%$. In the countries of EFTA (European Free Trade Association: Iceland, Norway, Liechtenstein, Switzerland), this share is $4.9 \%$, of which only Switzerland and Liechtenstein have a very high proportion ( $13.1 \%$ and $30.2 \%$, respectively). From a total of 350 000 organic producers in Europe, of which 270000 are even located in EU countries, the largest number concentrated in Turkey - about 70000 , then in Italy around - 53000 (Willer and Lernoud, 2017). In the period from 2006 to 2015, the number of organic producers increased by $72 \%$ in the EU by $50 \%$ in the last year, this increase amounts to only $4 \%$ of the entire European territory.

In the agricultural area, the largest share of the European continent occupies agricultural land (arable land), while the second - with a surface of 5.3 million 
hectares located permanent grassland, while the third permanent crops - with 1.4 million hectares (Table 4). When it comes to the EU, the arrangement of the area under organic production is somewhat different. Permanent grassland are located in the first position with a total of 5.1 million ha, followed by arable land (4.7 million ha) and permanent crops (1.2 million ha). FiBL data (2017) indicate that in all European countries, in the period from 2004 to 2015, the area for all land use types increased, however, in 2015, the only reduction was observed in permanent crops. The crop that covers most of the surface with this type of farming as cereals, which recorded a magnification as much as $13 \%$ (Willer et al., 2017). During the last decade, the area under organic production of permanent crops more than doubled, and recorded the highest growth compared with arable land and permanent grassland. Also, the largest growth among the main arable crop groups was recorded by dry pulses and oilseeds - $180 \%$, while the grain grew by $70 \%$ (FiBL, 2017).

Table 4. Europe and European Union: Key indicators 2015

\begin{tabular}{|c|c|c|c|}
\hline Indicator & Europe & $\begin{array}{c}\text { European } \\
\text { Union }\end{array}$ & $\begin{array}{c}\text { Top } 3 \text { countries } \\
\text { Europe }\end{array}$ \\
\hline $\begin{array}{l}\text { Organic } \\
\text { farmland } \\
\quad \text { (ha) }\end{array}$ & 12.7 milion ha & 11.2 milion ha & $\begin{array}{c}\text { Spain (1.97 million } \\
\text { ha) } \\
\text { Italy (1.49 million } \\
\text { ha) } \\
\text { France ( } 1.37 \text { million } \\
\text { ha) }\end{array}$ \\
\hline $\begin{array}{l}\text { Organic share } \\
\text { of total } \\
\text { farmland }\end{array}$ & $2.5 \%$ & $6.2 \%$ & $\begin{array}{c}\text { Liechtenstein } \\
(30.2 \%) \\
\text { Austria }(21.3 \%) \\
\text { Sweden }(16.9 \%)\end{array}$ \\
\hline $\begin{array}{c}\text { Growth of } \\
\text { organic } \\
\text { farmland 2014- } \\
2015 \\
\text { (ha) }\end{array}$ & 959.793 ha & 805.280 ha & $\begin{array}{l}\text { Spain }\left(+258^{\prime} 095 \text { ha }\right) \\
\text { France }(+256483 \text { ha }) \\
\text { Russia (+139’294 ha) }\end{array}$ \\
\hline $\begin{array}{c}\text { Growth of } \\
\text { organic } \\
\text { farmland 2014- } \\
2015 \\
(\%)\end{array}$ & $8.2 \%$ & $7.8 \%$ & $\begin{array}{c}\text { Serbia }(+60 \%) \\
\text { Bulgaria }(+59 \%) \\
\text { Russian Federation } \\
(+57 \%)\end{array}$ \\
\hline Land use & $\begin{array}{l}\text { Arable: } 5.7 \\
\text { million ha } \\
\text { Permanent }\end{array}$ & $\begin{array}{c}\text { Arable: } 4.7 \\
\text { million ha } \\
\text { Permanent crops }\end{array}$ & \\
\hline
\end{tabular}




\begin{tabular}{|c|c|c|c|}
\hline & $\begin{array}{l}\text { crops: } 1.4 \\
\text { million ha } \\
\text { Permanent } \\
\text { grassland: } \\
5.3 \text { million ha }\end{array}$ & $\begin{array}{c}1.2 \\
\text { million ha } \\
\text { Permanent } \\
\text { grassland: } \\
5.1 \text { million ha }\end{array}$ & \\
\hline $\begin{array}{l}\text { Top arable } \\
\text { crops }\end{array}$ & $\begin{array}{c}\text { Cereals: } 2.2 \\
\text { million ha; } \\
\text { Green fodder: } \\
2.1 \\
\text { million ha } \\
\text { Dry pules: } 0.3 \\
\text { million ha }\end{array}$ & $\begin{array}{l}\text { Green fodder: } \\
1.9 \\
\text { million ha } \\
\text { Cereals : } 1.7 \\
\text { million ha } \\
\text { Dry pules: } 0.3 \\
\text { million ha }\end{array}$ & $\begin{array}{l}\text { Largest arable areas: } \\
\text { France }(0.7 \text { million } \\
\text { ha }) \\
\text { Italy }(0.7 \text { million ha }) \\
\text { Spain }(0.5 \text { million ha }\end{array}$ \\
\hline $\begin{array}{c}\text { Top permanent } \\
\text { crops }\end{array}$ & $\begin{array}{l}\text { Olives: } 0.5 \\
\text { million ha } \\
\text { Grapes: } 0.3 \\
\text { million ha } \\
\text { Nuts: } 0.2 \text { million } \\
\text { ha }\end{array}$ & $\begin{array}{l}\text { Olives: } 0.45 \\
\text { million ha } \\
\text { Grapes: } 0.28 \\
\text { million ha } \\
\text { Nuts:0.19 } \\
\text { million ha }\end{array}$ & $\begin{array}{c}\text { Largest permanent } \\
\text { areas: } \\
\text { Spain }(0.5 \text { million } \\
\text { ha }) \text {, } \\
\text { Italy ( } 0.4 \text { million ha }) \\
\text { Turkey ( } 0.2 \text { million } \\
\text { ha }\end{array}$ \\
\hline $\begin{array}{l}\text { Wild collection } \\
\text { area }\end{array}$ & 17.7 milion ha & 15.4 milion ha & $\begin{array}{c}\text { Finland (12.2 million } \\
\text { ha }) \\
\text { Romania }(1.8 \text { million } \\
\text { ha; } 2014) \\
\text { Bulgaria: }(0.9 \text { million } \\
\text { ha })\end{array}$ \\
\hline Producers & $349^{\prime} 261$ & $269^{\prime} 453$ & $\begin{array}{c}\text { Turkey: 69'967 } \\
\text { Italy: 52'609 } \\
\text { Spain: 34'673 }\end{array}$ \\
\hline Processors & $60^{\prime} 073$ & $58 ' 360$ & $\begin{array}{c}\text { Italy }\left(14^{\prime} 658\right) \\
\text { Germany }\left(14^{\prime} 280\right) \\
\text { France }\left(11^{\prime} 842\right) \\
\end{array}$ \\
\hline Importers & $3^{\prime} 681$ & $3^{\prime} 474$ & $\begin{array}{l}\text { Germany (1'452) } \\
\text { Netherlands (314) } \\
\text { Italy (310 }\end{array}$ \\
\hline
\end{tabular}

(Source: Willer et al., 2017)

In Europe and the EU permanent grassland in the period from 2014 to 2015 recorded the largest increase surface - to $9 \%$. There was also recorded the increase of arable land (5.5\%), as opposed to permanent crops that was not significantly enlarged - only $2.7 \%$. The largest area under organic production of permanent grassland / grazing areas are located in Spain, Germany and the UK (Padel, 2017). When it comes to cropland areas (arable and permanent crops) the 
largest surface area are concentrated in Italy ( 0.9 million ha), Spain ( 0.8 million ha) and France ( 0.7 million ha). Due to the fact that in Europe the most grain products, most manufacturers of these types of crops in the EU are Italy, Germany and Spain, and Ukraine, Turkey and the Russian Federation (as a country outside the EU). Organic vegetable production on the European continent covers an area of 160000 ha, of which the largest producers of Poland, Italy, France and Spain. For one year, in the period from 2014 to 2015, there was a very large increase in oilseeds - $22 \%$, as well as vegetables $(19 \%)$ and cereals (17\%) (Willer et al., 2017; Lacarce, 2017 ).

\section{Organic production in Serbia}

Compared with neighboring countries, it is clear that Serbia under utilized natural resource that has. Around $90 \%$ of organic products from Serbia is focused on the markets of EU, US and Japan. Plan experts in the sphere of agriculture has a tendency to over the next decade under organic production in our country is more than $20 \%$ of arable land in the ground, ie. nearly one million hectares (Milenković and Tasić, 2013). In Serbia, the total area under organic (including surfaces with organic status and in the conversion period) spread 15.298 ha, of which 13,398 ha is from arable land, 1.899 ha meadows and pastures (The Ministry of Agriculture and Environment, 2017). In the period 2006-2012, the number of hectares under organic production increased by 15 times. When it comes to the number of manufacturers involved in the system of organic production, Serbia belongs to the leading countries in the region, where according to the Ministry of Agriculture and Environmental Protection (2017), has so far registered 334 organic producers. The data indicate that about $85 \%$ of manufacturers committed to organic crop production, and $15 \%$ for meat and fish. In relation to the entirety of Serbia's territory, most of these manufacturers located in Vojvodina (1/3) and then in the Western and Southern Serbia. In the structure of the most common vegetable organic products are perennial and annual varieties. Given that the average size of the used agricultural land per farm in Serbia about 5.4 ha (Vehapi, 2014), the most important is the production on a small organic property. In the past decade, the market has increased by over three times.

Types of organic products in Serbia according to the regions is given in table 5. Regional distribution of organic production in Serbia is given in table 5. The dominant role, with a surface area of 2.182 .89 ha, occupies the production of cereals (Fig. 7) (of which 2.069.05 ha is under the conversion period). Organic largest grain production takes place in the region Province of with a share of $91 \%$ in 2014 (2.583.54 ha), wherein for a period of one year the surface almost twice enlarged by presenting 4.045.57 ha in 2015 (Popović et al., 2017). Organic fruit production in Serbia takes the second position, with total surface area of 2.895.12 ha (Veličković and Golijan, 2016). Šumadija and Western Serbia characterized 
by the leading role of organic fruit growing (1.344.42 ha). Growing crops, meadows and pastures mainly spread in the region of South Serbia, known for its production of raspberries, blackberries, cherries, apples, plums and strawberries, which are successfully exported to foreign markets. "Ariljska" raspberry is highly valued in the international market, and what is very important, taking up as much as $30 \%$ of the total world production of raspberries (Milenković and Tasić, 2013).

Production of industrial crops in Serbia (tobacco, flax, poppy seeds, sorghum, soybean, sunflower, rapeseed), with an area of 2.674.38 ha in 2015 (The Ministry of Agriculture and Environment, 2017) is on the third position, behind the dominant cereals and fruits. When it comes to these kinds of plants and, Vojvodina also represents a region that extends its largest surface area is covered by organic products, where in the Južnobanatski district, county in which the highest production of this type of plantis constant, but the last three years.

Table 5. Organic production by regions in Serbia, in 2015

\begin{tabular}{|c|c|c|c|}
\hline Region & $\begin{array}{c}\text { Convers } \\
\text { ion period }\end{array}$ & $\begin{array}{c}\text { Organic } \\
\text { status }\end{array}$ & $\begin{array}{c}\text { Total } \\
\text { (ha) }\end{array}$ \\
\hline Belgrade & 11 & 49 & 60 \\
\hline $\begin{array}{c}\text { Sumadija and Western } \\
\text { Serbia }\end{array}$ & 791 & 709 & 1500 \\
\hline Southern and Eastern Serbia & 892 & 1698 & 2590 \\
\hline Vojvodina & 5975 & 5172 & 11147 \\
\hline Total & $\mathbf{7 6 6 9}$ & $\mathbf{7 6 2 9}$ & $\mathbf{1 5 2 9 8}$ \\
\hline
\end{tabular}

Source: Ministry of Agriculture and Environmental Protection, 2017

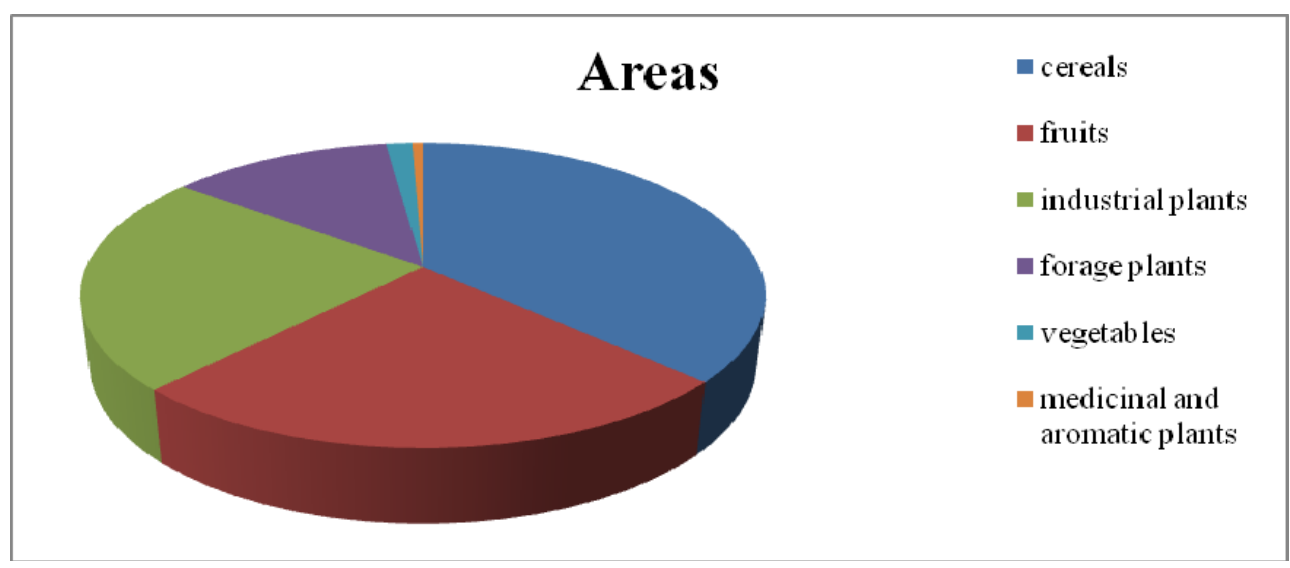

Figure 7. Area under organic crop production in Serbia in 2015

(Source: authors' calculations, based on data from the Ministry of Agriculture and Environmental Protection) 
Organic farming for vegetables covers an area of 170.5 ha (The Ministry of Agriculture and Environment, 2017), wherein the maximum production in a region Province of a share of $80 \%$ (136.59 ha). The most common types with the highest production areas under the system of the organic vegetable can be found in the production of bean (15.64 ha), popcorn (14.25 ha), potato (13.74 ha), jerusalem artichoke (12.84 ha), pumpkin (12.04 ha), pepper (10.38 ha) and onion (9.4 ha) (Golijan et al., 2017). Also, with respect to the entire territory of Serbia, -Vojvodina represents the region where extending of the largest area under organic potato (8.27 ha), popcorn (13.49 ha), bean (9.76 ha), pepper (9.73 ha), cucurbits (9.51 ha), carrot (8.26 ha), and cabbage (6.66 ha), and also, represents the only region where they produce artichoke, fennel, chickpeas, lentils, and asparagus.

The organic medicinal and aromatic plants in Serbia, in 2015, was carried out on an area of 70.94 ha (2.67 ha in the period of conversion to, and 68.27 ha in the organic status), covering at least the surface in comparison with the production of cereals, fruits, vegetables, industrial and fodder crops. Since the whole organic sector has a tendency of continuous growth, and thus the production of the plants in the country increased by 10.01 ha compared with the previous year 2014 (Golijan, 2016). The total turnover of medicinal plants in Serbia achieved by large - scale production (50\%) and the remainder (50\%) is provided by collecting the plants from the spontaneous flora. Highest production of medicinal and aromatic plants for organic farming system achieves region South and East Serbia, with a midpoint of 40.31 ha in 2015 (Golijan, 2016).

\section{Conclusion}

Numerous negative effects on the environment caused by conventional agriculture have led to alternative development trends in agriculture, among which organic farming occupies a special place. This type of farming is fully regulated by numerous regulations, and the very production methods are legally prescribed by the competent authorities. Globally, organic agricultural production in 2015 was carried out on an area of 50.9 million ha. The largest areas are located in Oceania (22.8 mil. ha), followed by Europe (12.7 mil. ha), while other locations include South America (6.7 mil. ha), Asia (around 4 million ha), North America (about 3 mil. ha) and Africa (1.7 mil.ha). As for the structure of the areas covered by organic products, grass areas make up the most thereof $(60 \%)$. In 2015, the largest increase in the organic farming area was recorded in Australia. Organic farming, as part of the global agricultural land, occupies only $1.1 \%$, whereby the surface under this type of agricultural production increased at an average annual rate of $6.7 \%$ change. When compared to neighboring countries, Serbia underutilizes extremely favourable natural conditions, suitable for the establishment of the organic farming areas, and hence agricultural experts 
plan to significantly increase the organic farming thereach area to reach the area of of about $1 \mathrm{mil}$. ha in the next 10 years (in 2015, these amounted to only 15298 ha).

\section{Literature}

Bähr M., Botschen M., Laberenz H., Naspetti S., Thelen E., Zanoli R. (2004): The European consumer and organic food (Vol. 4). School of Management and Business.

Beleski K., Boškov K., Bičikliski, O. (2012): Stanje i perspektive organskog vinogradarstva. Agroznanje, 13 (3): 363-374.

Berenji J. (2009): Uloga sorte i sortnog semena u organskoj poljoprivredi. Zbornik radova Naučnog instituta za ratarstvo i povrtarstvo Novi Sad, 46 (1): 11-16.

Bulatović L. (2011): Osnovna obeležja organske poljoprivrede. Agroekonomika, 49-50.

Conner D. S. (2004): Consumer preferences for organic standards: does the final rule reflect them? Journal of Sustainable Agriculture, 23 (3), 125-143.

Golijan J., Veličković M. (2015): Nutritivni sastav organski i konvencionalno proizvedenih namirnica. Hrana i ishrana, 56 (2): 43-46.

Golijan J. (2016): Organska proizvodnja lekovitog i aromatičnog bilja u Republici Srbiji. Lekovite sirovine, 36 (36): 75-83.

Golijan J., Popović A. (2016): Basic characteristics of the organic agriculture market. Fifth International Conference Competitiveness Of Agro-Food And Environmental Economy, 10-11 November 2016, Bucharest.

Golijan J., Živanović Lj., Popović A. (2017): "Status and areas under organic production of vegetables in the Republic of Serbia". $6^{\text {th }}$ International Symposium on Agricultural Sciences. AgroRes 2017, February 27-March 2, 2017 Banja Luka, Republic of Srpska, Bosnia and Herzegovina, pp 133.

Kalentić M., Stefanović E., Simić I., Maerz U. (2014). Organska poljoprivreda u Srbiji. Nacionalno udruženje za razvoj organske proizvodnje Serbia organica, Beograd. Retrieved December 3, 2016, from http://www.kombeg.org.rs/Slike/CeTranIRazvojTehnologija/2015/jun/Organska \%20poljoprivreda\%20u\%20Srbiji\%202014.pdf

Knickle K. (2000): Organic farming, good agricultural practices (GAP) and biodiversity-some key issues, IFOAM, Germany, 143-153.

Kolašinac S., Golijan J., Lekić S., Moravčević Đ., Popović A. (2017): Challenges and possibilities of organic seed production with the emphasis on control of pathogens. $6^{\text {th }}$ International Symposium on Agricultural Sciences. AgroRes 2017, February 27-March 2, 2017 Banja Luka, Republic of Srpska, Bosnia and Herzegovina, pp 143.

Kovačević D., Lazić B., Milić V. (2011): Uticaj poljoprivrede na životnu sredinu. Međunarodi naučni skup agronoma „Jahorina”.

Lacarce $\hat{E}$. (2017): The French organic food market. French organic farming Observatory. Biofach 2017, European Market. www.agencebio.org 
Marques Vieira L., Dutra De Barcellos M., Hoppe A., Bitencourt da Silva S. (2013): An analysis of value in an organic food supply chain. British Food Journal, 115 (10): 1454-1472.

Milenković S., Tasić J. (2013): Organska hrana kao perspektivni proizvod Srbije. Ekonomske teme, 51 (2): 411-424.

Mićić N., Janković R., Jovanović M., Korać M., Veličković, M. (1996): Dostignuća i savremene tendencije u agro-i pomotehnici voćaka. X Kongres voćara Jugoslavije, Čačak, 28.10-1.11.1996. Zbornik radova, 147-163.

Ministry of Agriculture and Environmental Protection (2017): http://www.mpzzs.gov.rs/ Retrived: 11.11.2017.

Mirecki N., Wehinger T., Jaklič M. (2011): Priručnik za organsku proizvodnju za poljoprivredne proizvođače. Food and Agriculture Organization of the United Nations (FAO), Podgorica. Retrived May 15, 2016, from http://www.fao.org/docrep/ 015/an443sr/an443sr00.pdf

Oljača S . (2012): Organska poljoprivredna proizvodnja. Zadužbina Andrejević, Beograd.

Padel S. (2017): UK organic sector and market trends 2015 and 16. Organic Research Centre. http://orgprints.org/31200/13/padel-2017-uk-marketbiofach2017.pdf

Popović A., Golijan J., Babić V., Kravić N., Sečanski M., Delić N. (2016): Organic farming as a factor for biodiversity conservation. International scientific conference on Ecological crisis: Technogenesis and climate change. Beograd, 21-23.april, 2016.

Popović A., Golijan J., Sečanski M., Čamdžija Z. (2017): "Current status and prospects of organic production of cereals in the world". $6^{\text {th }}$ International Symposium on Agricultural Sciences. AgroRes 2017, February 27March 2, 2017 Banja Luka, Republic of Srpska, Bosnia and Herzegovina.

Roljević S., Subić J., Potrebić V. (2009): Proizvodnja organske hrane na području Kolubarskog okruga atraktivne za plasman u Istarskoj Županiji. Tranzicija, 11 (23-24): 83-89.

Shi-mingl M., Sauerborn J. (2006): Review of History and Recent Development of Organic Farming. Agricultural Sciences in China, 6 (3): 170.

Schaack D. (2017): The organic market in Germany-highlights 2016. Agricultural market information company (AMI), 15.02.2017, Biofach, Nürnberg

Solfanelli F. (2017): The Italian market for organic food. Biofach 2017. http://orgprints.org/31200/25/solfanelli-2017-italian-market-biofach2017.pdf

Ugrenović V., Filipović V. (2012): Organska proizvodnja i biodiverzitet. II Otvoreni dani biodiverziteta, 26. Jun, Pančevo.

Vehapi S .Z . (2014): Marketing strategija proizvođača organske hrane. Doktorska disertacija.

Veličković M., Golijan J. (2015): Koncept integralne zaštite jabuke i kruške. Journal of Agricultural sciens, 60 (4): 381-393.

Veličković M., Golijan J., Popović A. (2016): Biodiversity and organic agriculture. Acta Agriculturae Serbica, XXI (42): 123-134.

Veličković M., Golijan, J. (2016): Organic Fruit Production in Serbia. Agro-knowledge Journal, 17 (3): 289-297. 
Vrdoljak M., Kegalj A., Čalić S. (2010). Ekološka proizvodnja zemalja srednje Europe. Stočarstvo, 63 (4), 297-308.

Willer H. (2017): European organic market data 2015. Research Institute of Organic Agriculture, FiBL, Frick, Switzerland (February 15, 2017)

Willer H., Lernooud J. (Eds.): The World of Organic Agriculture Statistics and Emerging Trends 2017. Research Institute of Organic Agriculture (FiBL), Frick, and IFOAM-Organics International, Bonn. http://www.organicworld.net/yearbook/yearbook-2017.html

Willer H., Schaack D., Lernoud J. (2017): Organic Farming and Market Development in Europe and the European Union. willer-etal-2017-europe.pdf

Zander K., Hamm U., Freyer B., Goessinger K., Naspetti S., Padel S., Zanoli R. (2011): Consumer concerns regarding additional ethical attributes of organic food. Organic is Life: Knowledge for tomorrow, 2: 22-24.

Šiljković Ž. (2002): Organska poljoprivreda Srednje Europe. Geoadria, 7 (2): 75-93.

www. fibl.org. Retrived: 20.2.2017.

www.fao.org/faostat/en/ Retrived: 20.2.2017

ec.europa.eu/eurostat Retrived: 20.2.2017. 


\title{
BILJNA PROIZVODNJA PO KONCEPTU ORGANSKE POLJOPRIVREDE U SVETU I REPUBLICI SRBIJI - ISTORIJAT I TRENUTNO STANJE
}

\author{
Jelena Golijan ${ }^{1}$, Milovan Veličković ${ }^{\text {, Bojan Dimitrijević }}{ }^{1}$ i Dimitrije \\ Marković ${ }^{2}$ \\ ${ }^{1}$ Poljoprivredni fakultet, Univerzitet u Beogradu, Beograd-Zemun, Srbija \\ ${ }^{2}$ Poljoprivredni fakultet, Univerzitet u Banja Luci, Banja Luka, Bosna i \\ Hercegovina \\ *e-mail:helena.ilios@gmail.com
}

\begin{abstract}
Rezime
Organska poljoprivredna proizvodnja, kao vid održive poljoprivrede, za razliku od konvencionalne poljoprivrede, svojim metodama proizvodnje povećava plodnost zemljišta, čuva i unapređuje njegov biodiverzitet, kao i biodiverzitet čitavog ekosistema, štiteći životnu sredinu, zdravlje biljaka, životinja i čoveka, uz primenu najviših standarda kvaliteta proizvodnje. Pojavljuje se početkom dvadesetog veka u Poljskoj, nastavljajući širenje u mnogobrojnim zemljama širom sveta do današnjih dana, te tako, u 2015. godini zauzima površinu od 50.9 miliona ha na globalnom nivou. Najveće površine pod ovim vidom poljoprivredne proizvodnje nalaze se u Okeaniji (22.8 miliona ha) i Evropi (12.7 miliona ha), pri čemu u strukturi površina dominiraju travne površine, a obradive čine svega 15\%. Na globalnom nivou, u toku perioda od 2014-2015. godine, površine su uvećane za 6.5 miliona ha. U 2015. godini, najveće uvećanje zabeleženo je u Okeaniji (za 23.2\%), kao i u 98 zemalja širom sveta, dok je pad zabeležen u 32 zemlje. U Evropi je skoncentrisana $1 / 4$ svetske organske proizvodnje. U Srbiji, organska proizvodnja se odvija na površini od 15298 ha (13398 ha pripada obradivom zemljištu, a 1899 ha livadama i pašnjacima), pri čemu se najveći broj proizvođača nalazi u Vojvodini, a zatim u Zapadnoj i Južnoj Srbiji. Žita, sa proizvodnim površinama od 2182.89 ha, zauzimaju vodeću ulogu. $\mathrm{S}$ obzirom na izuzetne potencijale za organsku proizvodnju u Srbiji, plan stručnjaka je da se u narednoj deceniji površine pod ovim vidom poljoprivredne proizvodnje uvećaju za $20 \%$.
\end{abstract}

Ključne reči: organska poljoprivreda, istorijski razvoj, zakonska regulativa, proizvodne površine. 